\title{
Weekly Variation of Rotavirus A Concentrations in Sewage and Oysters in Japan, 2014-2016
}

\author{
Erika Ito ${ }^{1}$, Jian Pu ${ }^{2, *}$, , Takayuki Miura ${ }^{3}{ }^{-0}$, Shinobu Kazama ${ }^{4}$, Masateru Nishiyama ${ }^{5}$, \\ Hiroaki Ito ${ }^{6}$, Yoshimitsu Konta ${ }^{7}$, Gia Thanh Nguyen ${ }^{8}\left(\mathbb{D}\right.$, Tatsuo Omura ${ }^{7}$ and Toru Watanabe ${ }^{5(D)}$ \\ 1 The United Graduate School of Agricultural Sciences, Iwate University, Iwate 020-8550, Japan \\ 2 Faculty of Information Networking for Innovation and Design, Toyo University, Tokyo 115-0053, Japan \\ 3 Department of Environmental Health, National Institute of Public Health, Saitama 351-0197, Japan \\ Department of Urban Engineering, The University of Tokyo, Tokyo 113-8656, Japan \\ Department of Food, Life and Environmental Sciences, Yamagata University, Yamagata 997-8555, Japan \\ 6 Center for Water Cycle, Marine Environment and Disaster Management, Kumamoto University, \\ Kumamoto 860-8555, Japan \\ 7 New Industry Creation Hatchery Center, Tohoku University, Miyagi 980-8579, Japan \\ 8 Department of Environmental and Occupational Health, College of Medicine and Pharmacy, Hue University, \\ Hue city 530000, Vietnam \\ * Correspondence: pu@toyo.jp; Tel.: +81-3-5924-2674
}

Received: 1 April 2019; Accepted: 23 June 2019; Published: 26 June 2019

check for updates

\begin{abstract}
Concentrations of rotavirus A, in sewage and oysters collected weekly from September 2014 to April 2016 in Japan, were investigated using RT-qPCR; results showed up to $6.5 \log _{10} \mathrm{copies} / \mathrm{mL}$ and $4.3 \log _{10}$ copies/g of digestive tissue (DT) in sewage and oysters, respectively. No correlation was found between rotavirus concentration in sewage and oysters and cases of rotavirus-associated gastroenteritis.
\end{abstract}

Keywords: rotavirus; oyster; sewage; real-time PCR

\section{Introduction}

Rotavirus is the major cause of acute gastroenteritis that leads to deaths in infants and young children worldwide. Before vaccines were introduced, rotavirus caused 20-40 deaths annually in the U.S. alone, and mortality was much higher in sub-Saharan Africa and South Asia [1,2]. Moreover, rotavirus was associated with up to $88 \%$ of all hospital-associated diarrheal episodes in Japan, before the introduction of vaccines, and led to $2-18$ deaths every year [3,4]. While rotavirus can infect all age groups, young groups are mainly affected. Among 4072 rotavirus-associated gastroenteritis cases during the period of 2005-2010 in Japan, approximately 75\% were 0- to 2-year-old babies [5]. Various vaccines have been licensed worldwide, including Rotarix, RotaTeq, Rotavac, and Rotasiil [6]. The first two have been commercially available in Japan since November 2011 and July 2012, respectively, for voluntary vaccination. Previous research has shown a decline of rotavirus deaths in 2013, after entering the vaccine era, but mortality in children $<5$ years remained high globally $(197,000-233,000$ deaths estimated) [7]. While norovirus has been well recognized to contaminate oysters, causing high levels of gastroenteritis in temperate regions during winter months, rotavirus was also detected in $0.3 \%$ to $16.7 \%$ of cases with oyster-associated gastroenteritis [8,9]. Although rotavirus has been detected in farmed oysters at rates of 3.3\%-44.4\% [9-11], information about their level of contamination in the environment and its seasonal variation remains limited. In this study, we performed long-term weekly monitoring of oysters at a cultivation site in Japan, tracking changes in viral loads across different seasons. The incidence of rotavirus in sewage in the same area was also simultaneously monitored, since it is likely to be the main source of rotavirus content in the oysters. 


\section{Results and Discussion}

Data related to rotavirus A contamination in sewage and oyster samples, as well as to gastroenteritis cases, are presented in Figure 1. Among the samples collected between 24 September 2014 and 21 April 2016, the highest rotavirus concentration obtained from sewage and oyster samples was $6.5 \log _{10}$ copies/mL and $4.3 \log _{10}$ copies/g of digestive tissue (DT), respectively. Approximately $62.2 \%$ (46 of 74 weeks) of sewage and $57.8 \%$ (37 of 64 weeks) of oyster samples were positive for rotavirus, which is much higher than the positivity rates reported in previous studies. In Thailand, rotavirus was detected in $27.1 \%$ (16 of 59 ), 9.1\% (5 of 55$)$, and $5.4 \%$ (5 of 110 ) of river water, irrigation canal water, and cultured oyster samples, respectively [10]. A wide range of positivity rates for rotavirus has been reported in oysters from different regions. Approximately $3.3 \%$ (5 of 150) of farmed oysters in China were found to be contaminated with rotavirus [11], whereas a comparatively higher positivity rate $(44.4 \%, 4$ of 9$)$ was found in oysters, related to an outbreak in Southern France [9]. However, we cannot deny the possibility that the positivity rate was influenced by differences in our detection methodologies.

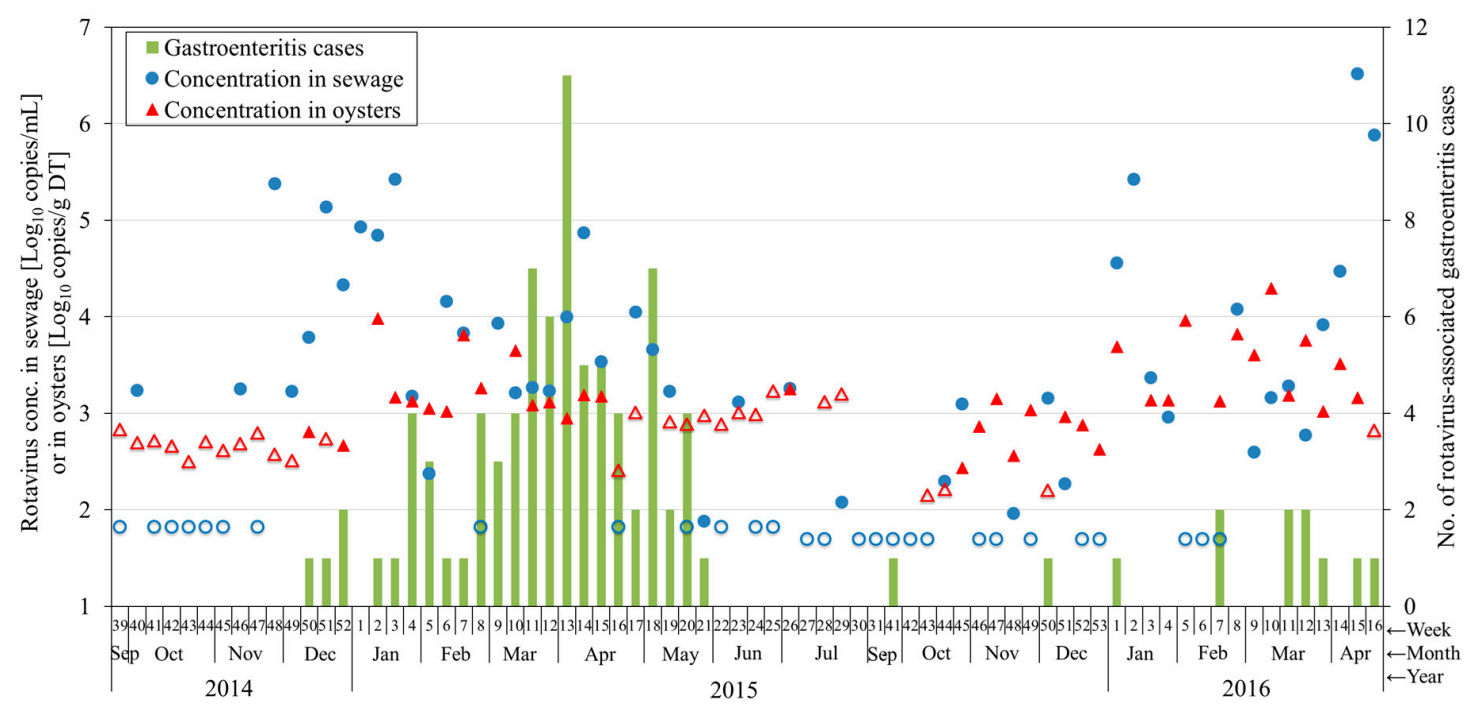

Figure 1. Rotavirus A concentration in sewage and oyster samples together with the number of rotavirus-associated gastroenteritis cases (green columns) in Miyagi, Japan. Empty circles and empty triangles represent half of the detection limit (LOD) in sewage and oysters, respectively, where rotavirus may exist, but below the detection limit. The weeks in which no oyster sample was collected or was tested positive due to low murine norovirus (MNV) recovery rate are considered invalid and left blank; The corresponding number of genomes for quantification cycles $\left(\mathrm{C}_{\mathrm{q}}\right.$ values $)$ of 40 varied across qPCR runs, and the weight of digestive tissue was different in each oyster sample. Thus, LOD for each sewage and oyster sample was different; half of LOD has been shown in the figure for convenience of presentation.

Humans, who consume oysters grown in contaminated water, are at a risk of rotavirus infection. Rotavirus concentrations reached $2.3 \log _{10} \mathrm{PFU} / \mathrm{g}$ DT in oysters cultured for $48 \mathrm{~h}$ in artificial seawater, containing $10^{4} \mathrm{PFU} / \mathrm{mL}$ of the rotavirus strain Wa [12]. In Japan, 1 of 286 fecal specimens was found to be positive for rotavirus in 88 oyster-associated gastroenteritis outbreaks [8]. Approximately $16.7 \%$ (2 of 12) of patients with shellfish-associated gastroenteritis shed rotaviruses, along with other viruses, such as astrovirus, Aichi virus, and enterovirus [9]. Our cross-correlation analysis found that $\log$ transformed norovirus GII concentrations in sewage and oysters was significantly correlated with the number of gastroenteritis cases in the same study area [13]; however, none of the cross-correlation coefficients in this study was statistically significant at the $95 \%$ confidence level. There are several possible explanations for this inconsistency. First, the number of rotavirus-associated gastroenteritis cases, reported each week, was small, ranging from 0 to 11 , and $56.8 \%$ of the weeks (42 of 74 ) reported 
no patient with rotavirus-associated disease, according to the Infectious Diseases Weekly Report of Miyagi Prefecture [14]. Second, shedding of rotavirus from domestic animals could cause a high load of rotavirus in seawater and oysters, whereas only those shed by humans could be detected in sewage, since over $99 \%$ of animal wastes do not enter municipal sewage system in Japan [15]. On the other hand, infants that receive rotavirus vaccine can shed up to $10^{7}$ copies in one gram of stool [16]; rotavirus vaccine (rotarix)-derived strains were found in six stool samples from pediatric clinics in Japan [17]. Therefore, there is a chance that feces from 5- or 6-month-old vaccinated babies also enter sewage, adding to the complexity of rotaviruses shed from humans. Third, despite the high concentration of rotavirus in seawater, caused by its low removal efficiency by wastewater treatment processes compared to that of norovirus [18,19], different stabilities were observed for different viruses in seawater [20], and different accumulation efficiencies in oysters were observed for different virus strains [21]. This could explain the weak correlations observed in this study. Weekly variation of rotavirus concentrations in sewage and oysters provide new insights into the distribution of rotavirus in wastewater, marine water, and shellfish.

\section{Materials and Methods}

Municipal sewage (1 L) and oyster (9 in number) samples were collected weekly (73 weeks in total) from Miyagi Prefecture, Japan, between 24 September 2014 and 21 April 2016. Virus particles were concentrated from sewage samples by polyethylene glycol precipitation [22]. Digestive tissue (DT) of each individual oyster was excised, and the virus extracted following a previously described protocol [23]. Approximately $1.5 \mathrm{~mL}$ viral supernatant was generated from each oyster. Three supernatants were pooled to form one oyster composite, and 3 oyster composites from each week were used for RNA extraction. Viral RNA was extracted from sewage and oyster samples as described earlier [23]. Complementary DNA (cDNA) was generated via reverse transcription using the iScript Advanced cDNA Synthesis Kit (Bio-Rad, Hercules, CA, USA) and a T100 thermal cycler (Bio-Rad), following the manufacturer's instructions. Rotavirus A was quantified from the cDNAs by quantitative real-time PCR (qPCR) targeting rotavirus on a CFX96 Touch Real-Time PCR Detection System (Bio-Rad), using previously developed primers and probes [24]. Murine norovirus (MNV) was added to samples during the viral extraction step as a whole-process control [22]. Samples with MNV recovery rates higher than 1\% were considered valid [25]. Quantification by qPCR was performed in accordance with the minimum information for the publication of real-time quantitative PCR experiments (MIQE) guidelines [26], and samples with quantification cycles $\left(\mathrm{C}_{\mathrm{q}}\right.$ values $)$ below 40 were considered positive for rotavirus.

Lag time ( \pm 7 weeks) was studied between log-transformed rotavirus concentrations in sewage and oyster samples (collected weekly) and the number of rotavirus-associated gastroenteritis cases reported weekly by 5 pediatric sentinel clinics in Miyagi Prefecture [15], using cross-correlation analysis [27]. A time-series cross-correlation coefficient of \pm 7 weeks was calculated to identify correlation between the following events: (1) Occurrence of gastroenteritis cases, (2) shedding of viruses from infected individuals into sewage, and (3) contamination of oysters with viruses. In samples where rotavirus was not detected positively, the incidence of rotavirus was estimated to be half of the limit of detection (LOD) to permit cross-correlation analysis [28,29].

Author Contributions: Conceptualization, T.W. and T.O.; sample process and qPCR analysis of oyster, E.I. and G.T.N.; sample process and qPCR analysis of sewage, S.K. and Y.K.; extraction method of oyster, H.I.; data analysis, J.P. and T.M.; original draft preparation, E.I. and J.P.; editing, J.P., T.M., M.N. and T.W.

Funding: This study was supported by the Japan Science and Technology Agency (JST) through a Core Research for Evolutionary Science and Technology (CREST) program, "Innovation of water monitoring system with rapid, highly precise and exhaustive pathogen detection technologies", and JSPS KAKENHI Grant Number $18 \mathrm{H} 03792$.

Acknowledgments: A murine norovirus strain S7-PP3 was kindly provided by Yukinobu Tohya (Nihon University, Japan).

Conflicts of Interest: The authors declare no conflict of interest. 


\section{References}

1. Desselberger, U. Rotaviruses. Virus Res. 2014, 190, 75-96. [CrossRef] [PubMed]

2. $\quad$ Estes, M.K.; Greenberg, H.B. Rotaviruses. In Fields Virology, 6th ed.; Fields, B.N., Knipe, D.M., Howley, P.M., Eds.; Wolters Kluwer Health/Lippincott Williams Wilkins: Philadelphia, PA, USA, 2013; pp. 1347-1401.

3. Zhou, Y.M.; Li, L.; Kim, B.; Kaneshi, K.; Nishimura, S.; Kuroiwa, T.; Nishimura, T.; Sugita, K.; Ueda, Y.; Nakaya, S.; et al. Rotavirus infection in children in Japan. Pediatr. Int. 2000, 42, 428-439. [CrossRef] [PubMed]

4. Ministry of Health, Labour and Welfare (MHLW). Rotavirus QAs. Available online: https://www.mhlw.go. jp/bunya/kenkou/kekkaku-kansenshou19/Rotavirus/index.html (accessed on 8 March 2019).

5. National Institute of Infectious Disease (NIID). Report of Rotavirus on 15 May 2013. Available online: https://www.niid.go.jp/niid/ja/diseases/a/echinococcus/392-encyclopedia/3377-rota-intro.html (accessed on 8 March 2019).

6. Desselberger, U. Differences of Rotavirus Vaccine Effectiveness by Country: Likely Causes and Contributing Factors. Pathogens 2017, 6, 65. [CrossRef] [PubMed]

7. Tate, J.E.; Burton, A.H.; Boschi-Pinto, C.; Parashar, U.D. World Health Organization-Coordinated Global Rotavirus Surveillance Network. Global, Regional, and National Estimates of Rotavirus Mortality in Children $<5$ Years of Age, 2000-2013. Clin. Infect. Dis. 2016, 62, S96-S105. [PubMed]

8. Iritani, N.; Kaida, A.; Abe, N.; Kubo, H.; Sekiguchi, J.; Yamamoto, S.P.; Goto, K.; Tanaka, T.; Noda, M. Detection and genetic characterization of human enteric viruses in oyster-associated gastroenteritis outbreaks between 2001 and 2012 in Osaka City, Japan. J. Med. Virol. 2014, 86, 2019-2025. [CrossRef] [PubMed]

9. Le Guyader, F.S.; Le Saux, J.C.; Ambert-Balay, K.; Krol, J.; Serais, O.; Parnaudeau, S.; Giraudon, H.; Delmas, G.; Pommepuy, M.; Pothier, P.; et al. Aichi virus, norovirus, astrovirus, enterovirus, and rotavirus involved in clinical cases from a French oyster-related gastroenteritis outbreak. J. Clin. Microbiol. 2008, 46, 4011-4017. [CrossRef]

10. Kittigul, L.; Panjangampatthana, A.; Rupprom, K.; Pombubpa, K. Genetic diversity of rotavirus strains circulating in environmental water and bivalve shellfish in Thailand. Int. J. Environ. Res. Public Health 2014, 11, 1299-1311. [CrossRef] [PubMed]

11. Kou, X.X.; Wu, Q.P.; Wang, D.P.; Zhang, J.M. Simultaneous detection of norovirus and rotavirus in oysters by multiplex RT-PCR. Food Control 2008, 19, 722-726. [CrossRef]

12. Araud, E.; DiCaprio, E.; Ma, Y.; Lou, F.; Gao, Y.; Kingsley, D.; Hughes, J.H.; Li, J. Thermal inactivation of enteric viruses and bioaccumulation of enteric foodborne viruses in live oysters (Crassostrea virginica). Appl. Environ. Microbiol. 2016, 82, 2086-2099. [CrossRef]

13. Pu, J.; Miura, T.; Kazama, S.; Konta, Y.; Azraini, N.D.; Ito, E.; Ito, H.; Omura, T.; Watanabe, T. Weekly variations in norovirus genogroup II genotypes in Japanese oysters. Int. J. Food Microbiol. 2018, 284, 48-55. [CrossRef]

14. Miyagi Prefectural Government (MPG). Infectious Diseases Weekly Report of Miyagi Prefecture. Available online: https://www.pref.miyagi.jp/site/hokans/surveypdf-shuho.html (accessed on 13 March 2018).

15. Ministry of Agriculture, Forestry and Fisheries (MAFF). Survey Results of Animal Waste in Japan. Available online: http://www.maff.go.jp/j/chikusan/kankyo/taisaku/pdf/syori-joukyou.pdf (accessed on 31 May 2019).

16. Hsieh, Y.C.; Wu, F.T.; Hsiung, C.A.; Wu, H.S.; Chang, K.Y.; Huang, Y.C. Comparison of virus shedding after lived attenuated and pentavalent reassortant rotavirus vaccine. Vaccine 2014, 32, 1199-1204. [CrossRef] [PubMed]

17. Kaneko, M.; Takanashi, S.; Thongprachum, A.; Hanaoka, N.; Fujimoto, T.; Nagasawa, K.; Kimura, H.; Okitsu, S.; Mizuguchi, M.; Ushijima, H. Identification of vaccine-derived rotavirus strains in children with acute gastroenteritis in Japan, 2012-2015. PLoS ONE 2017, 12, e0184067. [CrossRef] [PubMed]

18. Kitajima, M.; Iker, B.C.; Pepper, I.L.; Gerba, C.P. Relative abundance and treatment reduction of viruses during wastewater treatment processes-Identification of potential viral indicators. Sci. Total Envron. 2014, 488-489, 290-296. [CrossRef] [PubMed]

19. Miura, T.; Schaeffer, J.; Le Saux, J.C.; Le Mehaute, P.; Le Guyader, F.S. Virus type-specific removal in a full-scale membrane bioreactor treatment process. Food Environ. Virol. 2017, 10, 176-186. [CrossRef] [PubMed]

20. De Abreu Corrêa, A.; Souza, D.S.; Moresco, V.; Kleemann, C.R.; Garcia, L.A.; Barardi, C.R. Stability of human enteric viruses in seawater samples from mollusc depuration tanks coupled with ultraviolet irradiation. J. Appl. Microbiol. 2012, 113, 1554-1563. [CrossRef] [PubMed] 
21. Le Guyader, F.S.; Atmar, R.L.; Le Pendu, J. Transmission of viruses through shellfish: When specific ligands come into play. Curr. Opin. Virol. 2012, 2, 103-110. [CrossRef]

22. Kazama, S.; Masago, Y.; Tohma, K.; Souma, N.; Imagawa, T.; Suzuki, A.; Liu, X.; Saito, M.; Oshitani, H.; Omura, T. Temporal dynamics of norovirus determined through monitoring of municipal wastewater by pyrosequencing and virological surveillance of gastroenteritis cases. Water Res. 2016, 92, 244-253. [CrossRef]

23. Pu, J.; Kazama, S.; Miura, T.; Azraini, N.D.; Konta, Y.; Ito, H.; Ueki, Y.; Cahyaningrum, E.E.; Omura, T.; Watanabe, T. Pyrosequencing analysis of norovirus genogroup II distribution in sewage and oysters: first detection of GII.17 Kawasaki 2014 in oysters. Food Environ. Virol. 2016, 8, 310-312. [CrossRef]

24. Pang, X.L.; Lee, B.; Boroumand, N.; Leblanc, B.; Preiksaitis, J.K.; Yu Ip, C.C. Increased detection of rotavirus using a real time reverse transcription-polymerase chain reaction (RT-PCR) assay in stool specimens from children with diarrhea. J. Med. Virol. 2004, 72, 496-501. [CrossRef]

25. ISO 15216-1. Microbiology of the Food Chain-Horizontal Method for Determination of Hepatitis A Virus and Norovirus Using Real-Time RT-PCR- Part 1: Method for Quantification. Available online: https://www.iso.org/standard/65681.html (accessed on 20 March 2018).

26. Bustin, S.A.; Benes, V.; Garson, J.A.; Hellemans, J.; Huggett, J.; Kubista, M.; Mueller, R.; Nolan, T.; Pfaffl, M.W.; Shipley, G.L.; et al. The MIQE guidelines: minimum information for publication of quantitative real-time PCR experiments. Clin. Chem. 2009, 55, 611-622. [CrossRef]

27. Kazama, S.; Miura, T.; Masago, Y.; Konta, Y.; Tohma, K.; Manaka, T.; Liu, X.; Nakayama, D.; Tanno, T.; Saito, M.; et al. Environmental surveillance of norovirus genogroups I and II for sensitive detection of epidemic variants. Appl. Environ. Microbiol. 2017, 83, e03406-e03416. [CrossRef] [PubMed]

28. LaFleur, B.; Lee, W.; Billhiemer, D.; Lockhart, C.; Liu, J.; Merchant, N. Statistical methods for assays with limits of detection: Serum bile acid as a differentiator between patients with normal colons, adenomas, and colorectal cancer. J. Carcinog. 2011, 10, 12. [CrossRef] [PubMed]

29. Whitcomb, B.W.; Schisterman, E.F. Assays with lower detection limits: implications for epidemiological investigations. Paediatr. Perinat. Epidemiol. 2009, 22, 597-602. [CrossRef] [PubMed]

(C) 2019 by the authors. Licensee MDPI, Basel, Switzerland. This article is an open access article distributed under the terms and conditions of the Creative Commons Attribution (CC BY) license (http://creativecommons.org/licenses/by/4.0/). 